\title{
The Application of the Statistical Methods to Measure the Effect of Adding a Bamboo Fiber and Combine it with Animal Collagen on the Physical, Chemical and Sensory Characteristics of Nags Tilapia Fish
}

\author{
Shabnam Kazemi Nia Gazi, Seyed Ebrahim Hosseini, Siamak Haji Yakhchali, Meysam Borajee
}

\begin{abstract}
Production the healthy and desirable products is the most essential tasks of food producing industries. Therefore, the food industry engineers by using the new techniques and new food sources to improve the quality and nutritional characteristics of food, change the food formulation while maintaining the desirable sensory characteristics. Fish nuggets is a product with low fiber content and high in fat, because of its preparation process (frying). So, investigating the feasibility of improving the fiber content and reducing the fat content of fish nuggets by using the appropriate resources is one of the essential tasks of meat and fish industry researchers. In this study we sought to evaluate different statistical methods and choice of appropriate analysis of variance to assess the effect of bamboo fiber and combine it with animal collagen on the physical and chemical characteristics and sensory Nags Tilapia fish are. So that we can properly and appropriately assess the effects of these additives on food. In this study, we sought to evaluate different statistical methods and select the appropriate analysis of variance to assess the effect of bamboo fiber and its combine with animal collagen on the physical, chemical and sensory characteristics of Nags Tilapia fish. So that we can measure the effects of these additives on food properly and appropriately.
\end{abstract}

Keywords-Application of the Statistical Methods, A Bamboo Fiber, Animal Collagen on the Physical, Chemical and Sensory Characteristics of Nags Tilapia Fish

\section{INTRODUCTION}

$\mathrm{U}$ RBAN population growth and industrialization has increased the tendency to ready to eat products. Among the ready food, food products derived of fish due to favorable nutritional characteristics, have a special place. People motivation on a diet of fish have been raised according to the lack of protein in most human societies, as well as the benefits of using of protein in fish and the positive effects of polyunsaturated fatty acids on human health with an abundance of seafood (Sargent et al., 1999).

However one limitation of using the fish and seafood, is the time-consuming process of cleaning and preparing the product. Curing fish and production of ready products, has been resolve the consumer problem in cleaning and readying to cook the

University of Tehran, Iran fish and leads the consumers to ready seafood consumption by creating diversity in aquatic products. On the other hand processing of fish that harvested fish during the limited period, gradually and all year long have presented to the market.

Edible fibers are bunch of useful nutritional compounds that including combine of carbohydrate polymers of plant oligosaccharides and polysaccharides such as: cellulose, hemicellulose, pectic materials, resins, resistant starch and inulin, which may be associated with lignin or other noncarbohydrate compounds (such as: polyphenols, wax, saponins, cotinine, phytate and resistant protein) (Fuentes Zaragoza et al., 2010). Edible fibers not only aren't hydrolysis, digested and absorbed in the small intestine human, but also increases the stool bulk, stimulates the fermentation in colon and reduce the cholesterol in blood glucose level (Elleuch et al., 2011). It was also reported that using of edible fibers carries another health effects, such as: reducing the risk of heart disease, diabetes, obesity and some types of cancer for consumers (Mann and Cummings, 2009). Using of edible fibers addition to improving the nutritional characteristics can reduce oil uptake in fried food products, because of their friendship water.

During a research Jamshidi and Shabanpour (2013) were added a cellulose methyl hydroxypropyl soluble fiber into a pupl fish nuggets. The result of this research showed that adding fiber can reduce the moisture loss and absorption of oil during the frying process. Choe et al (2013) were investigated the effect of combine the pig skin and wheat fiber as fat alternative on meat quality characteristics. Results of this research showed that adding the combine was increase the moisture content and protein and reduce the fat content product. The results showed that the samples with a combine of pig skin and wheat fiber than the control samples, has a cooking loss. Also adding a combine of pig skin and wheat fiber were become the firmness, consistency, resinous and chewing the sausage samples. Sensory evaluation results indicated that there is no significant negative impact of mixed skins and wheat fiber on consumer acceptance.

Huda et al (2013), examined the effect of adding the duck 
leg collagen on the physical and chemical characteristics of Surimi. Generally the results of this research showed that collagen duck leg than the fish and cow collagen had a significant impact on improving the quality features of Surimi such as: cooking loss, gel strength, color and hardness.

Petracci et al (2013) examined the effect of pragmatic additives on the chicken meat products and in this researches showed that adding the animal collagen more than $3.5 \%$ improves the tissue and increases the water holding capacity and stability of the fat.

Prestcs et al. (2013) examined the effect of collagen and its degree of commination on the quality of chicken ham. The results of this research showed that the addition of collagen to product as well as smaller particle size, associated the better quality characteristics for products. Sensory measures results was indicated the acceptance of products contain collagen by the consumers.

Santhi and Kalaaikannan (2014), have examined the effect of oat flour on qualitative characteristics of chicken nuggets. The results of this research showed that oat flour addition is reducing the cooking loss and fat content and increasing the moisture and a fiber content, increasing the stiffness, adhesion, cohesion of product.

Kim et al (2015) studied the effect of edible fiber wheat addition on qualitative characteristics of chicken nuggets. Results showed that chicken nuggets with edible fiber have accruing efficiency than the control samples. Also the results of sensory evaluation suggests that was no signification effect of adding the edible fiber wheat on sensory characteristics of chicken nuggets.

Hom et al (2015), were studied the effect of fat replacing with a combine of collagen and edible fiber (cellulose derivatives) in fermented sausages. Results of this research showed that thiobarbituric acid during storage period in samples with fiber and collagen was lower than the control samples. Also, the fat content of samples was reduce and its moisture, protein and ash content affected by adding the combine of fiber and collagen was increase a lot.

Zeng et al (2016) showed that by using of edible fiber bamboo sprouts in fiber fish with bread covered and its combine with egg whites, this combination reduces the oil uptake and moves the moisture from center to surface in deep frying. Therefore, this study attempts to examine the amount of effects the addition of plant additives such as bamboo fiber and their

TABLE I

BAMBOo CHEMICAL COMBINATION (Li, 2004)

\begin{tabular}{|c|c|c|c|c|c|c|c|}
\hline Year & $\begin{array}{l}\text { Part of } \\
\text { stems }\end{array}$ & $\begin{array}{l}\text { Ash } \\
\text { (Percent) }\end{array}$ & $\begin{array}{l}\text { Compounds of } \\
\text { dissolved in water } \\
\text { (percent) }\end{array}$ & $\begin{array}{l}\text { Compounds of dissolved } \\
\text { in alcohol (percent) }\end{array}$ & $\begin{array}{l}\text { Lignin } \\
\text { (Percent) }\end{array}$ & $\begin{array}{l}\text { Holo-cellulose } \\
\text { (Percent) }\end{array}$ & $\begin{array}{l}\text { Alpha-cellulose } \\
\text { (Percent) }\end{array}$ \\
\hline \multirow{3}{*}{1} & Down & 1.82 & 5.83 & 3.32 & 21.98 & 68.92 & 46.52 \\
\hline & Center & 1.94 & 5.07 & 2.86 & 22.11 & 70.84 & 47.30 \\
\hline & Top & 1.95 & 5.14 & 3.48 & 21.26 & 71.95 & 47.51 \\
\hline \multirow{3}{*}{3} & Down & 1.30 & 6.33 & 4.17 & 23.21 & 68.58 & 46.21 \\
\hline & Center & 1.36 & 6.91 & 4.38 & 23.95 & 72.69 & 46.82 \\
\hline & Top & 1.41 & 7.43 & 5.21 & 23.71 & 73.82 & 46.99 \\
\hline \multirow{3}{*}{5} & Down & 1.26 & 4.89 & 6.61 & 22.93 & 69.94 & 48.08 \\
\hline & Center & 1.30 & 5.19 & 6.81 & 22.97 & 72.50 & 47.65 \\
\hline & Top & 1.35 & 5.84 & 7.34 & 23.02 & 73.65 & 47.91 \\
\hline
\end{tabular}

combined with animal collagen on the physical, chemical and sensory characteristics of Nags tilapia fish. This study has four section. In the second section, the problem is described completely. In the third section, the assumption category tests was described and the suitable assumption test was select and proposed. In the final section, the conclusion of this study is state.

\section{II.PROBLEM STATEMENT}

Tilapia fish is species of fish, due to breeding facility and marketable, has a many supporters around the world. Today more than 100 countries to foster, china is a largest producer of tilapia in the world. This fish is the second farmed fish after crap, so we can fostered it with various and inexpensive foods. Different types of tilapia is used in the aquaculture that its most important commercial type is Nile tilapia with the scientific name Oreochromis niloticus. Including fast foods of fish can mentioned to fish burger, fish finger, fish sausage and fish nugget. Tilapia fish nuggets is a product that prepared of combine the parts of tilapia fish with additive and several favors. The combine of tilapia fish with additive after forming the coating process with the dough before frying (frying minor) and then packaged and stored at a temperature of ${ }^{\circ} \mathrm{C}$ 20- and before eating it be fried (Ojagh et al., 2013).

Most of the various meat products and fish are rich in fat and protein but unfortunately face a shortage of carbohydrate such as edible fibers. Therefore, the use of food fibers in meat products is recommended. Bamboo is a common expression that use for about 1250 species of plants (grass wood) with a height of $10 \mathrm{~cm}$ to 40 meters (Scurlock et al., 2000). Bamboo is as a good source for dietary fiber, a pragmatic combined with extensive industrial applications. Bamboo is rich in fiber composition that can be a source of hope is part of the food industry. Bamboo chemical compounds are summarized in Table 1 have been reported. Bamboo ash content is composed of minerals, silica, calcium, potassium and manganese $(\mathrm{Li}$, 2004). 
Collagen is another compounds that used in the meat industry. Collagen is one of the functional compounds in the food industry which improves the technological characteristics of the products. Collagen plays a major role in tissue of meat and meat products. The Collagen that from various sources over the years, used as a suitable compounds to improve the keep of waters and fat in meat products. Also at low levels, Collagen can be used in the stabilizing shrinkage and texture of the manipulating (Prabhu et al., 2004). In addition, Collagen have been used such as other protein components to reduce oil absorption during frying other food products. Inhibitory effects of protein components of than the oil absorption, can be caused by its feature of film formation and thermal Zhlasyun (Brannan et al., 2014). So according the mentioned items in this study, different methods of variance analysis have been studied that can measure the effect of adding bamboo fiber and animal Collagen on the physical and chemical characteristics and organoleptic and nutritional of tilapia fish nugget.

\section{Statistical MethodS}

Several statistical methods used to compare the impact average of one or more independent variables on the one dependent variable based on various experimental designs. But in cases where more than one dependent variable is considered, have been used multivariate analysis methods according to the dependencies between the dependent variables. Before choosing a statistical test should be specific as follows:

\begin{tabular}{|l|l|}
\hline Needed information & Existing research \\
\hline $\begin{array}{l}\text { The number of variables under } \\
\text { investigation }\end{array}$ & $\begin{array}{l}\text { In this study, we have two } \\
\text { independent variables and the } \\
\text { three dependent variables }\end{array}$ \\
\hline $\begin{array}{l}\text { The number of comparison } \\
\text { groups }\end{array}$ & 5 Groups \\
\hline Distribution features investigated & normal distribution \\
\hline Independence groups investigated & Dependent \\
\hline Data Type & Relative quantitative data \\
\hline
\end{tabular}

Now with this information and according to following table can be chose the appropriately test.

\begin{tabular}{|l|l|l|l|}
\hline $\begin{array}{l}\text { Nominal } \\
\text { qualitative data }\end{array}$ & $\begin{array}{l}\text { Data ranking or } \\
\text { abnormal } \\
\text { qualitative data }\end{array}$ & $\begin{array}{l}\text { Quantitative } \\
\text { data with } \\
\text { normal } \\
\text { distribution }\end{array}$ & Target \\
\hline Ratio test & Median test & $\begin{array}{l}\text { Mean and } \\
\text { standard } \\
\text { deviation test }\end{array}$ & Describes a group \\
\hline $\begin{array}{l}\text { Chi-square test } \\
\text { or binomial test }\end{array}$ & Wilcoxon test & One sample test & $\begin{array}{l}\text { Compare a group } \\
\text { with an assumed } \\
\text { value }\end{array}$ \\
\hline $\begin{array}{l}\text { Fisher's exact } \\
\text { test (chi-square } \\
\text { test for large } \\
\text { samples) }\end{array}$ & $\begin{array}{l}\text { Mann- } \\
\text { Whitney test }\end{array}$ & $\begin{array}{l}\text { Test for } \\
\text { independent } \\
\text { samples }\end{array}$ & $\begin{array}{l}\text { Compare two } \\
\text { independent } \\
\text { groups }\end{array}$ \\
\hline Mac- Nar test & Kruskal test & Paired -test & $\begin{array}{l}\text { Compare the two } \\
\text { dependent groups }\end{array}$ \\
\hline Chi-square test & Wallis test & $\begin{array}{l}\text { One-way } \\
\text { analysis of } \\
\text { variance test }\end{array}$ & $\begin{array}{l}\text { Compare three or } \\
\text { more } \\
\text { (independent) }\end{array}$ \\
\hline Cochran test & Friedman test & $\begin{array}{l}\text { Analysis of } \\
\text { variance with } \\
\text { repeated } \\
\text { measures test }\end{array}$ & $\begin{array}{l}\text { Compare three or } \\
\text { more (dependent) }\end{array}$ \\
\hline
\end{tabular}

\begin{tabular}{|l|l|l|l|}
\hline $\begin{array}{l}\text { Coefficient of } \\
\text { agreement test }\end{array}$ & $\begin{array}{l}\text { Spearman } \\
\text { correlation } \\
\text { coefficient test }\end{array}$ & $\begin{array}{l}\text { Pearson } \\
\text { correlation } \\
\text { coefficient test }\end{array}$ & $\begin{array}{l}\text { Measuring } \\
\text { correlation } \\
\text { between two } \\
\text { variables }\end{array}$ \\
\hline $\begin{array}{l}\text { Logistic } \\
\text { regression test }\end{array}$ & $\begin{array}{l}\text { Non-parametric } \\
\text { regression test }\end{array}$ & $\begin{array}{l}\text { Simple } \\
\text { regression or } \\
\text { nonlinear test }\end{array}$ & $\begin{array}{l}\text { Prediction of a } \\
\text { variable based on } \\
\text { one or more } \\
\text { variables }\end{array}$ \\
\hline
\end{tabular}

As is clear, if the input data was as abnormal then should be used the Friedman test, otherwise, should be used the variance analysis test with repeated measures. The variance analysis test with repeated measures is as a extended of paired test, The difference is that instead of comparing one group in the two situation, a group of two or more items are compared. When the same measuring to be made for several times from a subject or a case, should be used the analysis of variance with repeated measures for data analysis and comparison of data averages of these times. However, if exist the between groups factors, then it can be analyzed by defining groups. With this statistical method we can test the null hypotheses about the effects of factors between and within groups. It can also to be measured the interactions effect between factors (both within the group and between groups) or more simply as the interaction effect of two or more independent variables. In addition, there is a possibility of covariance analysis on the factors within the group and between the group and its interaction with these factors. It can examined the effect of fixe variable as covariance (or variable) and statistically controlled its intervention effect on the dependent variable.

\section{CONCLUSION}

Over the past decades, tends to be the types of food has changed with consumer awareness of the relationship between health and food. Food not only consumed to stave off hunger and provide basic nutritional needs, but also used to prevent diseases related to nutrition and improve mental and physical consumers. In this regard, pragmatic combinations of food can be provide a good opportunity to improve the nutritional quality of food products for producers. First, the fortification of foods was done with vitamins and minerals to produce functional foods, then the food fortification go to the use of micronutrients and fiber edible. According to the survey, since the number of selected groups in this study are more than three groups and they are dependent data, if the data are normally distributed best choice test should be repeated measures ANOVA test and if the data do not follow the normal distribution function the Friedman test is the best choice..

\section{REFERENCES}

[1] Brannan, R. G., Mah, E., Schott, M., Yuan, S., Casher, K. L., Myers, A., \& Herrick, C. (2014). Influence of ingredients that reduce oil absorption during immersion frying of battered and breaded foods. European Journal of Lipid Science and Technology, 116(3), 240-254. https://doi.org/10.1002/ejlt.201200308

[2] Choe, J-H., Kim, K-Y., Lee, J-M., Kim, Y-J., \& Kim, C-J. (2013).Quality of frankfurter-type sausages with added pig skin and wheat fiber mixture as fat replacers. Meat Science, 93,849-854. https://doi.org/10.1016/j.meatsci.2012.11.054 
[3] Elleuch, M., Bedigian, D., Roiseux, O., Besbes, S., Blecker, C., \& Attia, H. (2011). Dietary fibre and fibre-rich by-products of food processing: Characterisation, technological functionality and commercial applications: A review. Food Chemistry, 124(2), 411-421. https://doi.org/10.1016/j.foodchem.2010.06.077

[4] Fuentes-Zaragoza, E., Riquelme-Navarrete, M. J., Sánchez-Zapata, E. \& Pérez-Álvarez, J. A. (2010). Resistant starch as functional ingredient: A review. Food Research International, 43(4), 931-942. https://doi.org/10.1016/j.foodres.2010.02.004

[5] Ham, Y-K., Hwang, K-E., Kim, H-W., Song, D-H., Kim, Y-J., Choi, YS., \& Kim, C-J. (2016). Effects of fat replacement with a mixture of collagen and dietary fibre on small caliber fermented sausages. International Journal of Food Science and Technology, 51, 96-104. https://doi.org/10.1111/ijfs. 12960

[6] Heng Zeng, Jiwang Chen, Jinling Zhai, Haibin Wang, Wenshui Xia,Youling L. Xiong (2016). Reduction of the fat content of battered and breaded fish balls during deep-fat frying using fermented bamboo shoot dietary fiber, LWT Food Science and Technology, 73, 425-431 https://doi.org/10.1016/j.lwt.2016.06.052

[7] Huda, N., Seow, E. K., Normawati, M. N., Nik Aisyah, N. M., Fazilah, A.\& Easa, A. M. (2013). Effect of duck feet collagen addition on physicochemical properties of surimi. International Food Research Journal, 20(2), 537-544.

[8] Jamshidi, A., and B. Shabanpour (2013) The effect of hydroxypropyl methylcellulose (HPMC) gum added to predust and batters of Talang Queen fish (Scomberoides commersonnianus) nuggets on the quality and shelf life during frozen storage (-18C). World, 5, 382-391.

[9] Kim, H. Y., Kim, K. J., Lee, J. W., Kim, G. W., Choe, J. H., Kim, H. W., ... \& Kim, C. J. (2015). Quality Evaluation of Chicken Nugget Formulated with Various Contents of Chicken Skin and Wheat Fiber Mixture. Korean Journal for Food Science of Animal Resources, 35(1), 19. https://doi.org/10.5851/kosfa.2015.35.1.19

[10] Li, X. 2004. Physical, Chemical, And Mechanical Properties Of Bamboo And Its Utilization Potential For Fiberboard Manufacturing, MS thesis, Louisiana State University and Agriculture and Mechanical College, China.

[11] Mann, J. I. \& Cummings, J. H. (2009). Possible implications for health of the different definitions of dietary fibre. Nutrition, Metabolism and Cardiovascular Diseases, 19, 226-229. https://doi.org/10.1016/j.numecd.2009.02.002

[12] Ojagh, S. M., Shabanpour, B., \& Jamshidi, A. (2013). The effect of different pre-fried temperatures on physical and chemical characteristics of silver carp fish (hypophthalmichthysmolitrix) nuggets. World J Fish Marine Sci, 5(4), 414-420.

[13] Petraccia, M., Bianchib, M., Mudalala, S., and Cavania, C., (2013) Functional ingredients for poultry meat .Food Science \& Technology 33 (2013) 27e39

[14] Prabhu, G. A., Doerscher, D. R., \& Hull, D. H. (2004). Utilization of pork collagen protein in emulsified and whole muscle meat products. Journal of food science, 69(5), C388-C392. https://doi.org/10.1111/j.1365-2621.2004.tb10703.x

[15] Prestes, R. C., Graboski, A., Roman, S. S., Kempka, A. P., Toniazzo, G., Demiate, I. M., \& Luccio. M. D. (2013). Effects of the addition of collagen and degree of comminution in the quality of chicken ham. J. Appl. Poult. Res, 22, 885-903. https://doi.org/10.3382/japr.2013-00809

[16] Santhi, D., \& Kalaikannan, A. (2014).The Effect of the Addition of Oat Flour in Low-Fat Chicken Nuggets. Nutrition \& Food Sciences, 4, 1-4.

[17] Sargent, J., Bell, G., McEvoy, L., Tocher, D., \& Estevez, A. (1999). Recent developments in the essential fatty acid nutrition of fish. Aquaculture, 177(1), 191-199. https://doi.org/10.1016/S0044-8486(99)00083-6

[18] Scurlock, J. M. O., Dayton, D. C., \& Hames, B. (2000). Bamboo: An overlooked biomass resource . Biomass and bioenergy, 19(4), 229-244. https://doi.org/10.1016/S0961-9534(00)00038-6 